\title{
Chahdortt Djavann, Comment peut-on être français?
}

\section{Veronica Amadessi}

\section{(2) OpenEdition}

\section{Journals}

\section{Édition électronique}

URL : http://journals.openedition.org/studifrancesi/9060

DOI : 10.4000/studifrancesi.9060

ISSN : 2427-5856

\section{Éditeur}

Rosenberg \& Sellier

\section{Édition imprimée}

Date de publication : 1 octobre 2008

Pagination : 500

ISSN : 0039-2944

\section{Référence électronique}

Veronica Amadessi, « Chahdortt Djavann, Comment peut-on être français? », Studi Francesi [En ligne], 155 (LII | II) | 2008, mis en ligne le 30 novembre 2015, consulté le 08 janvier 2021. URL : http:// journals.openedition.org/studifrancesi/9060; DOI : https://doi.org/10.4000/studifrancesi.9060

Ce document a été généré automatiquement le 8 janvier 2021.

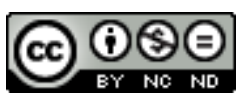

Studi Francesi è distribuita con Licenza Creative Commons Attribuzione - Non commerciale - Non opere derivate 4.0 Internazionale. 


\title{
Chahdortt Djavann, Comment peut-on être français?
}

\author{
Veronica Amadessi
}

\section{RÉFÉRENCE}

CHAHDORTT DJAVANN, Comment peut-on être français?, Paris, Flammarion, 2006, pp. 285.

1 Le personnage principal de ce roman, Roxane, est une jeune fille née dans les montagnes de l'Azerbaïdjan. Petite-fille d'un gouverneur assassiné qui parlait français, elle décide de se rendre à Paris, «son fantasme à elle». Après avoir loué une chambre de bonne, elle part à la découverte de la ville de ses rêves, qu'elle trouve merveilleuse et surprenante. En observant les monuments, les transports en commun, l'abondance des marchandises au supermarché, elle reste abasourdie par la richesse et la diversité, et elle s'abandonne à la découverte; des comparaisons s'imposent par rapport à son pays, l'Iran, où elle n'a pas pu goûter à la liberté de vivre comme elle l'entendait. Sa carte de séjour obtenue, Roxane doit ensuite apprendre la langue française et trouver un travail. Cependant, ses efforts au travail et l'amitié la liant à son voisin ne parviennent pas à combler sa solitude. Le monde qu'elle avait cru pouvoir dominer et comprendre reste mystérieux, obscur, la langue française apparaît plus difficile que prévu, même un geste banal demande un effort remarquable. C'est alors que, au cours de civilisation française de la Sorbonne, Roxane découvre les Lettres persanes. La lecture de Montesquieu suscite en elle un processus d'identification avec l'héroïne du roman, car les deux Roxane se ressemblent effectivement beaucoup; indépendantes, rebelles, elles pourraient être deux réalisations différentes d'une même entité. Voilà alors que l'imagination pousse la jeune fille à considérer le personnage littéraire comme un être ayant vraiment vécu et son auteur défunt comme un homme encore vivant. Par conséquent, Roxane décide d'écrire des lettres à Montesquieu, sans tenir compte de l'impossibilité objective d'obtenir une réponse de la part du destinataire. 
2 La narration s'organise par la suite autour de deux voix: d'un côté, celle qui raconte les événements concernant la vie de Roxane et de l'autre celle de Roxane elle-même signant ses lettres. Les deux plans narratifs s'alternent tout au long du récit, permettant ainsi au lecteur de saisir les pensées du personnage et de découvrir en même temps ce que le personnage ne veut pas raconter. Comme dans un processus de dédoublement de personnalité, chaque narrateur assume l'histoire que l'autre ne veut pas ou ne peut pas raconter. L'échange épistolaire à une seule voix, celui avec l'homme de lettres, est pourtant à lui seul riche, cocasse, amusant, car il traite des sujets les plus différents et remet en question les valeurs occidentales ainsi que les mœurs orientales avec une ironie intelligemment dosée. Les dix-huit lettres, reportant toutes une adresse différente, abordent aussi les problèmes des deux sociétés et envisagent parfois des solutions. Pourtant, un léger malaise s'insinue petit à petit dans la narration, faisant surgir un souvenir terrible et une sensation de solitude aiguë qui amènent Roxane à la dépression. Le passé l'ayant rattrapée, elle s'adonne à un portrait final d'elle-même où le désespoir semble avoir gagné, tout en laissant envisager au lecteur une issue moins tourmentée grâce à l'image symbolique du ciel bleu qui filtre de la lucarne.

3 La romancière de succès Chahdortt Djavann nous offre avec ce roman un portrait plein de charme et de tendresse, dans un style à la fois ingénu et subtil, traversé par les sentiments propres à tous les immigrés: le doute, l'espoir, la solitude. 